Rev. Int. Contam. Ambie. 34 (1) 69-77, 2018

DOI: 10.20937/RICA.2018.34.01.06

\title{
HISTOPATHOLOGICAL CHANGES IN LIVER AND GILLS OF Odontesthes bonariensis INHABITING A LAKE WITH HIGH CONCENTRATIONS OF ARSENIC AND FLUORIDE (CHASICÓ LAKE, BUENOS AIRES PROVINCE)
}

\author{
María Laura PUNTORIERO*, Alicia FERNÁNDEZ CIRELLI and Alejandra Vanina VOLPEDO
}

Universidad de Buenos Aires, Facultad de Ciencias Veterinarias, Centro de Estudios Transdisciplinarios del Agua; Consejo Nacional de Investigaciones Científicas y Técnicas, Instituto de Investigaciones en Producción Animal, Av. Chorroarín 280- C1427CWO, Buenos Aires, Argentina

*Corresponding author; mlpuntoriero@gmail.com

(Received November 2016; accepted May 2017)

Key words: histopathology, trace elements, silverside, Argentina

\begin{abstract}
Water bodies in the Chaco-Pampean plain contain arsenic (As) and fluoride (F) occurring naturally. Chasicó Lake, located in the southwest of Buenos Aires Province, has high concentrations of both elements (As, 0.05-0.41 mg/L; F- 6.74-8.54 mg/L). Fish can be considered as indicators of environmental pollution. The aim of this study was to analyze whether the presence of high concentrations of As and $\mathrm{F}^{-}$found in the liver and gills of Odonthestes bonariensis could be associated to histological changes found in these tissues. Fish were sampled from different locations of the lake. Tissue samples (liver and gills) were subdivided and subjected to an acid digestion to determine As and to an alkaline digestion to determine $\mathrm{F}^{-}$. Morphological changes were assessed using routine histological techniques. As concentrations in the liver were higher than in the gills, while the gills showed higher $\mathrm{F}^{-}$concentrations. The histological examination of the liver and gills showed alterations that could correspond to the effects of the high As and $\mathrm{F}^{-}$concentrations found in these tissues. The toxicity of these elements is due to oxidative stress. Silverside is one commercially relevant fish in Buenos Aires and a key species in the food chain in the region. Therefore, further histopathological studies are relevant to guarantee this fish's health and safety for human consumption.
\end{abstract}

Palabras clave: histopatología, elementos traza, pejerrey, Argentina

\section{RESUMEN}

Los cuerpos de agua de la llanura Chaco-Pampeana contienen arsénico (As) y fluoruro $\left(\mathrm{F}^{-}\right)$cuyo origen es natural. El Lago Chasicó, ubicado en el sudoeste bonaerense, presenta elevadas concentraciones de ambos elementos (As: $0.05-0.41 \mathrm{mg} / \mathrm{L} ; \mathrm{F}^{-}: 6.74-8.54$ $\mathrm{mg} / \mathrm{L}$ ). Los peces pueden considerarse como indicadores de contaminación ambiental. El objetivo de este estudio fue analizar si la presencia de altas concentraciones de As y $\mathrm{F}^{-}$halladas en hígado y branquias de Odonthestes bonariensis pudiera estar asociada con los cambios histológicos encontrados en estos tejidos. Los peces fueron colectados en diferentes localidades del lago. Se subdividieron muestras de tejidos (hígado y branquias) y se sometieron a una digestión ácida para determinar As y a una digestión 
alcalina para determinar $\mathrm{F}^{-}$. Los cambios morfológicos se determinaron mediante técnicas histológicas de rutina. En hígado se hallaron concentraciones de As más altas que en branquias, mientras que las branquias mostraron concentraciones de $\mathrm{F}^{-}$más elevadas. El examen histológico del hígado y las branquias mostró alteraciones que podrían corresponder a los efectos de las altas concentraciones de As y $\mathrm{F}^{-}$halladas en esos tejidos. La toxicidad de estos elementos se debe al estrés oxidativo. El pejerrey es uno de los peces comerciales más importantes de Buenos Aires y una de las especies clave de la cadena alimenticia en la región, por lo que resultan relevantes estudios histopatológicos adicionales para asegurar la salud de los peces y su inocuidad para el consumo humano.

\section{INTRODUCTION}

The Chaco-Pampean plain is one of the largest plains in the world and it has As and $\mathrm{F}^{-}$occurring naturally in different water bodies (Schenone et al. 2007, Rosso et al. 2011a, b, Avigliano et al. 2015). Chasicó Lake is the water body with highest concentrations of both elements (As, $0.05-0.41 \mathrm{mg} / \mathrm{L} ; \mathrm{F}^{-}$, 6.74-8.54 mg/L) (Puntoriero et al. 2014a). This lake is characterized by its high salinity $(>35 \mathrm{~g} / \mathrm{L})$, and its aquatic ichthyofauna is restricted to a single species: the silverside (Odontesthes bonariensis).

As and $\mathrm{F}^{-}$are associated to toxic trace elements since both elements come from the Pampean loess originated from volcaniclastic sediments (Smedley and Kinniburgh 2002). These elements are relevant in aquatic trophic chains because they can be biotransferred to different food chain levels, including humans (USEPA 1989, 1993). Fish can be considered as indicator organisms of environmental pollution (Metcalfe-Smith et al. 2003, Bhatnagar and Regar 2005, Bhatnagar et al. 2007). This is because they are constantly exposed to toxic elements dissolved in water, through gill breathing and epidermis contact (Gernhöfer et al. 2001, Bears et al. 2006).

The mechanisms of As incorporated into fish are unclear; there are only a few studies about the detoxification mechanism (Wrobel et al. 2002, Bears et al. 2006). Regarding $\mathrm{F}^{-}$, studies analyzing its biotransference from water to fish tissues are also scarce (Haque et al. 2012, Cao et al. 2013, Puntoriero et al. 2014b).

High As concentrations in water cause in fish tegument discoloration, histological changes in gills and liver, slow growth and low efficiency in feed conversion (Russell et al. 2010). As for $\mathrm{F}^{-}$, high concentrations can lead to different toxic effects, such as decreased growth and development, behavioral changes, delay in fertilized egg hatching, histological changes in gills and liver, changes in bone tissue, metabolic disorders and increase in mortality (Chitra et al. 1983, Camargo 2003, Metcalfe-Smith et al.
2003, Bhatnagar and Regar 2005, Bhatnagar et al. 2007, Kumar et al. 2007, Shi et al. 2009).

The liver is the main metabolic fish organ and it plays an important role in the uptake, accumulation, biotransformation and excretion of toxic elements (Pedlar et al. 2002). In relation to As, several studies have reported liver fibrosis, hepatocellular damage, cell edema, focal necrosis areas in addition to hepatocellular carcinoma (Liu et al. 2001, ATSDR 2002, Datta et al. 2009). $\mathrm{F}^{-}$plays an important causal role in cell apoptosis (Wang et al. 2004). Histopathological changes reported in liver by fluoride toxicity of Cyprinus carpio and Channa punctatus include vacuolar degeneration, increasing sinusoidal space and focal necrosis areas with nuclear pyknosis (Haque et al. 2012, Cao et al. 2013).

The gills are important organs that fulfill multiple functions, including gas exchange, osmotic pressure regulation, acid-base balance and ion transport. All these actions are closely related to gill chloride cells (Mallatt 1985, Mallatt and Stinson 1990) and they are one of the entryways for toxins in fish (Hughes 1984). Once the gills are damaged, the gas exchange and osmotic regulation functions could be affected, resulting in physiological and histological changes in fish (Haque et al. 2012).

Odontesthes bonariensis is a commercially relevant native species, typically found in the Pampean plain. The aim of this manuscript was to analyze whether the presence of high concentrations of As and $\mathrm{F}^{-}$in the liver and gills of Odonthestes bonariensis in Chasicó Lake are associated with histological anomalies occurring in these tissues.

\section{MATERIAL AND METHODS}

\section{Study area}

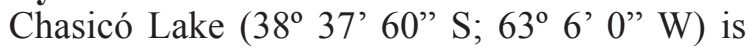
located in the southwest of Buenos Aires Province (Fig. 1). It is an endorheic system that receives waters 


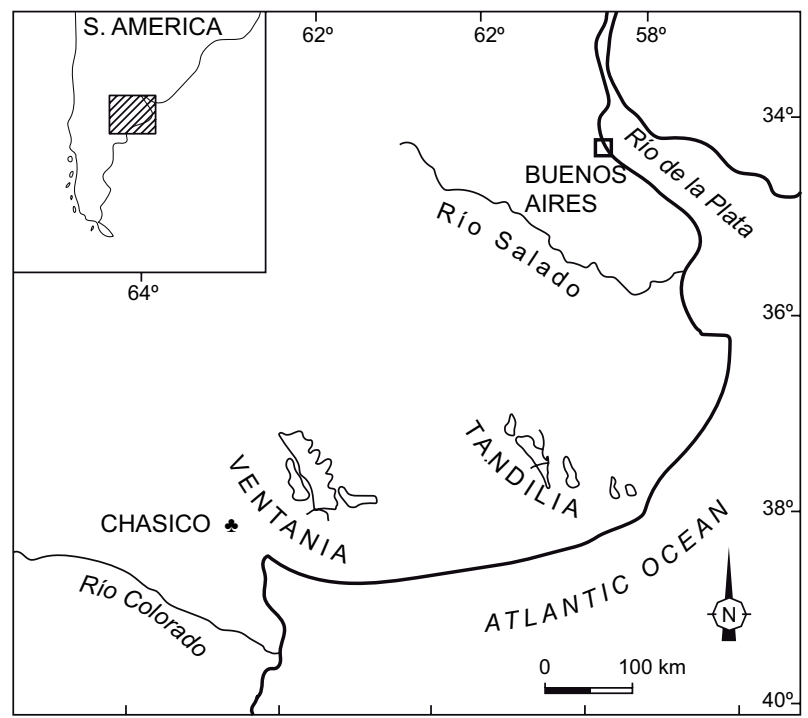

Fig. 1. Study area

from the Chasicó Stream and drains into the Ventania system. It is situated on a tectonic belt located more than $20 \mathrm{~m}$ below sea level, on the southwest slopes of the orographic Ventania system. This strip extends in a northwest to southeast direction, parallel to the tectonic pit inside which the Colorado River is located. The late Tertiary succession of the southern Pampean region comprises an extensive plateau capped by a thick calcrete crust, which in turn is covered by a thin mantle of late Pleistocene-Holocene eolian deposits (Zárate et al. 2007). The lake is recharged by direct precipitation, a groundwater system and surface runoffs from a catchment basin of $3.764 \mathrm{~km}^{2}$ (Bonorino et al. 1989). The Chasicó Lake surface area was $31 \mathrm{~km}^{2}$ in 1963, it increased to $85 \mathrm{~km}^{2}$ in 2003-2004 and decreased to $50.3 \mathrm{~km}^{2}$ to this date (Remes and Colautti 2003). This may be the result of natural flood and drought periods, which are reflected in its salinity and aquatic biota changes. The average maximum depth of this water body is $16 \mathrm{~m}$.

\section{Sampling and analytical methods}

Fish $(n=30)$ were sampled in different locations of the lake (Fig. 2) using appropriate fishing gear (trammels, long lines). The total length was measured using an ictiometer $( \pm 0.1 \mathrm{~cm})$, then samples were weighed with a Sartorius ED224S extend analytical balance $( \pm 0.001 \mathrm{~g})$, and then the fish sex was determined. Tissue samples ( $0.5 \mathrm{~g}$ each) were subdivided and subjected to an acid digestion to determine As concentration (APHA, 1995) and to an alkaline digestion to determine $\mathrm{F}^{-}$concentration (Kjellevold Malde et al. 2001). The fourth gills were sampled from both sides of the fish. Arsenic concentrations were determined by inductively coupled plasma optical emission spectrometry (ICP-OES), using a Perkin Elmer Optima $2000 \mathrm{DV}$, and fluoride was determined by the electrometric method of fluoride selective electrode. A macroscopic analysis of fish was carried out in order to find tegument discoloration and changes in the spine curvature. The histopathological analysis was performed using routine histological techniques (H \& E, Giemsa, Trichrome).

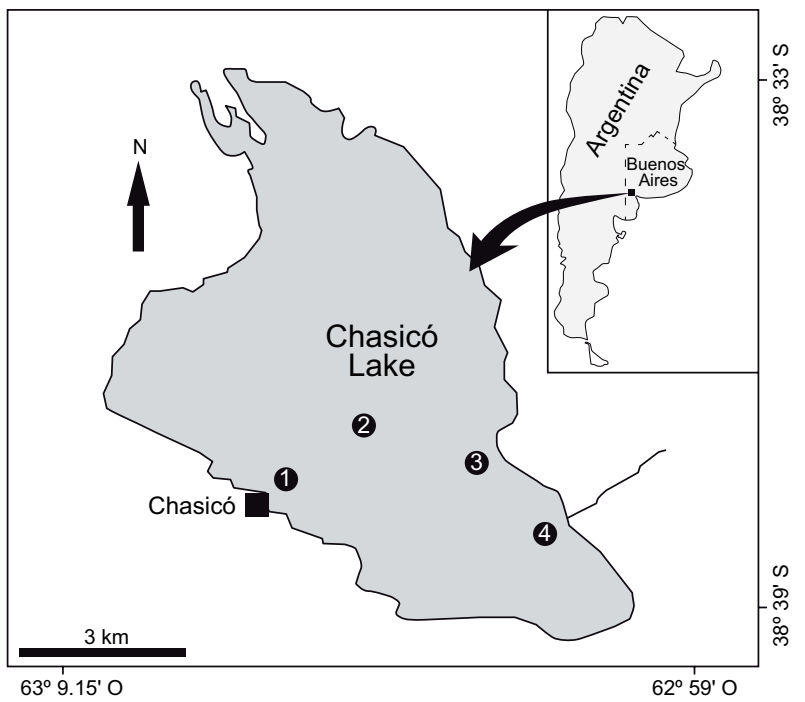

Fig. 2. Sampling locations of Chasicó Lake

\section{Statistics}

The software used in the statistical analysis was Statistica 6 (Statsoft). Pearson correlation was used to analyze organs pathologies $(\mathrm{p}<0.05)$.

\section{RESULTS AND DISCUSION}

The length of fishes ranged from 39.2 to $42.5 \mathrm{~cm}$ $(39.3 \pm 0.22)$, with a proportion of 25 females and 5 males. Tables I and II show the results of different As and $\mathrm{F}^{-}$concentrations in liver and gills of Odontesthes bonariensis and other species, in dry weight. The highest values of As were found in the liver vs. the gills, both in silverside and other species (Table I). The $\mathrm{F}^{-}$concentration in the gills was higher than in the liver (Table II), results that agree with previous reports for Acipencer baerii in the same tissues (Shi et al. 2009).

The fish macroscopic analysis did not show tegument discoloration or abnormal curvature of the spine. No microscopic differences were found in the liver and gills among the Chasicó Lake sampling 
TABLE I. ARSENIC CONCENTRATION (IN $\mu \mathrm{g} / \mathrm{g}$ DRY WEIGHT) IN LIVER AND GILLS OF Odontesthes bonariensis SAMPLED IN CHASICÓ LAKE, BUENOS AIRES, ARGENTINA

\begin{tabular}{lcclccl}
\hline & \multicolumn{2}{c}{ Liver } & & \multicolumn{2}{c}{ Gills } & \\
\cline { 2 - 3 } & Mean $\pm \mathrm{sd}$ & Average & & Mean $\pm \mathrm{sd}$ & Average & \\
\hline Catla catla & $3.90 \pm 0.18$ & $3.51-10.90$ & & $7.70 \pm 1.1$ & $1.01-10.4$ & Shah et al. (2009) \\
Alosa immaculata & $4.94 \pm 1.20$ & $3.69-6.38$ & & $1.53 \pm 0.33$ & $1.25-2.01$ & Visnjic-Jeftic et al. (2010) \\
Acipenser ruthenus & $0.52 \pm 0.82$ & $0-2.55$ & & $0.04 \pm 0.14$ & $0-0.65$ & Jarić et al. (2011) \\
Odontesthes bonariensis & $3.03 \pm 0.87$ & $0.24-8.98$ & & $4.16 \pm 0.53$ & $0.77-8.91$ & This work \\
\hline
\end{tabular}

Data are expressed as mean \pm standard deviation

TABLE II. FLUORIDE CONCENTRATION (IN $\mu \mathrm{g} / \mathrm{g}$ DRY WEIGHT) IN LIVER AND GILLS OF Odontesthes bonariensis SAMPLED IN CHASICÓ LAKE, BUENOS AIRES, ARGENTINA

\begin{tabular}{lcccccc}
\hline & \multicolumn{2}{c}{ Liver } & & \multicolumn{2}{c}{ Gills } & \\
\cline { 2 - 3 } & Mean $\pm \mathrm{sd}$ & Average & & Mean $\pm \mathrm{sd}$ & Average & \\
\hline Acipencer baerii & $39.01 \pm 3.60$ & $36.80-51$ & & $169.61 \pm 5.21$ & $158-181.20$ & Shi et al. (2009) \\
Odontesthes bonariensis & $33.71 \pm 23.51$ & $7.10-75.30$ & & $72.11 \pm 12.02$ & $49.10-110-10$ & This work \\
\hline
\end{tabular}

Data are expressed as mean \pm standard deviation

sites. Several histological changes were observed in the liver of $95 \%$ of the samples, with the most common ones being dilation and congestion in blood vessels, hemosiderin, dilation and congestion in hepatic sinusoidal, loss of contact between hepatocytes and pancreocytes, cellular degeneration, focal necrosis areas and cellular apoptosis (Fig. 3b-e). Also, peliosis areas in the hepatic parenchyma were found, indicative of coagulative necrosis areas (Fig. 3f).
All samples showed histopathological changes in the gills, including edema in secondary lamellae and epithelial detachment, curling of secondary lamellae, congestion and telangiectasia in blood vessels of gill filaments and hyperplasia of mucous cells (Fig. 4 b-f).

Pearson correlation analysis evidenced that there is a significant positive correlation between the presence of hemosiderin in the liver and congestion in blood vessels $(r=0.50 ; p<0.05)$ and hepatic peliosis
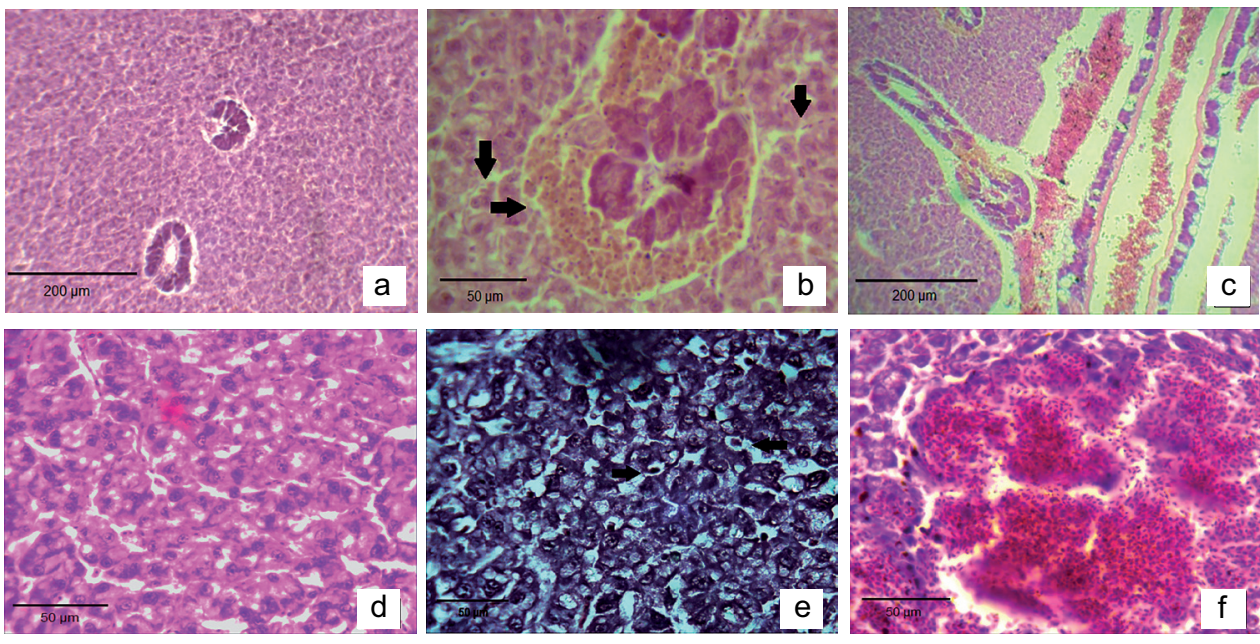

Fig. 3. (a) Liver of control fish $(10 \times)$. (b) Hemosiderin in hepatopancreas and dilation in blood sinusoids $(40 \times)$. (c) Dilation and congestion in blood vessels $(10 \times)$. (d) Cellular degeneration and dilation in blood sinusoids $(40 \times)$. (e) Focal necrosis area and nuclear pyknosis $(40 \times)$. (f) Peliosis area $(40 \times)$ 

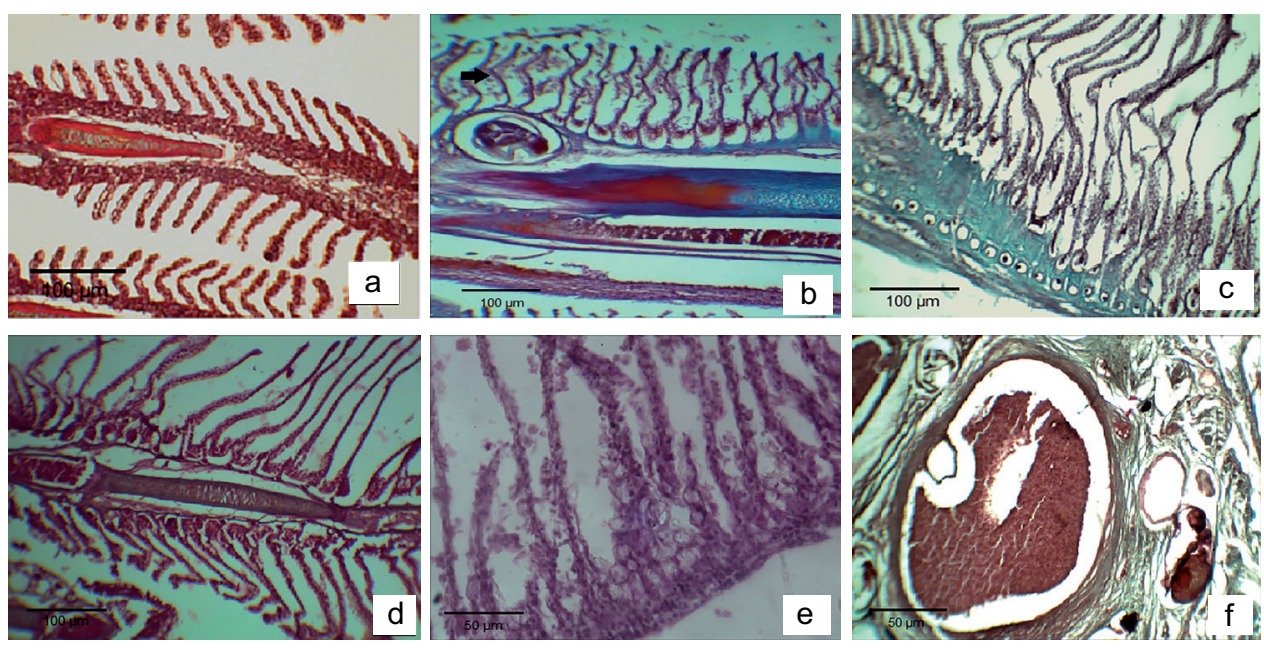

Fig. 4. (a) Gills of control fish $(10 \times)$. (b) Edema in secondary lamellae and epithelial detachment $(10 \times)$. (c) Epithelial detachment and curling of secondary lamellae (10×). (d) Curling of secondary lamellae $(10 \times)$. (e) Hyperplasia of mucous cells $40(40 \times)$. (f) Congestion and telangiectasia in blood vessels in gill filaments $(40 \times)$

areas $(\mathrm{r}=0.52 ; \mathrm{p}<0.05)$. In addition, focal necrosis areas correlated significantly with cell degeneration $(r=0.60 ; p<0.05)$. Regarding the occurrence of the pathologies identified in both organs, it was observed that congestion in blood vessels and cell degeneration in liver is more closely associated with epithelium detachment $(r=0.43$ and 0.51 , respectively; $\mathrm{p}<0.05)$ and the curling of the secondary gill lamellae $(r=0.45$ and 0.47 , respectively; $\mathrm{p}<0.05$ ).

The Chasicó Lake's silverside liver and gills showed high concentrations of As and $\mathrm{F}^{-}$. The values of both trace elements found in silverside were similar to those reported by other authors in liver and gills (Shah et al. 2009, Shi et al. 2009, Višnjić-Jeftić et al. 2010, Jarić et al. 2011). In both tissues the values exceeded the maximum allowed levels according to the Argentine Food Code (1985) (As: $1 \mu \mathrm{g} / \mathrm{g}, \mathrm{F}^{-}: 1.5 \mu \mathrm{g} / \mathrm{g}$ ). However, the population would not be at risk because these tissues are not consumed in the country.

The histopathological study of silverside liver and gills showed alterations caused by the toxic effects of these trace elements. Oxidative stress is a recognized mode of action of As and $\mathrm{F}^{-}$that has been observed in soft tissues such as liver, gills, kidney and brain. Both trace elements increase the generation of anion superoxide $\left(\mathrm{O}_{2}{ }^{-}\right)$, hydrogen peroxide and peroxynitrite, resulting in the accumulation of proteins in the endoplasmic reticulum (ER) causing ER stress and reactive oxygen species (ROS) production in cell mitochondria (Ghosh et al. 2008). It is known that excessive ROS production leads to macromolecular oxidation, resulting in free radical attack of membrane phospholipids with resulting membrane damage via induction of lipid peroxidation, mitochondrial membrane depolarization and apoptosis (Barbier et al. 2010). Also, ROS inhibit the activity of antioxidant enzymes such as superoxide dismutase (SOD), catalase (García-Montalvo et al. 2009), glutathione reductase (GR) and glutathione $\mathrm{S}$ transferase (GST) (Schuliga et al. 2002, Bhattacharya and Bhattacharya 2007), leading to more damage of cellular components. In addition, fluoride may cause an inhibitory effect in enzymes of the glycolytic pathway and the Krebs cycle. $\mathrm{Na}^{+} / \mathrm{K}^{+}$-ATPases are also inhibited, leading to ATP depletion and a disturbance in cell membrane potential. Therefore, fluoride ions inhibit cellular respiration and decrease the production of ATP (Schuliga et al. 2002).

Liver is the main organ of various key metabolic pathways. One of the most sensitive organs is the teleost liver, which shows alterations in its histoarchitecture, biochemistry, and physiology following exposure to various types of environmental pollutants. The histological changes in silversides in Chasicó Lake showed cellular degeneration and focal necrosis areas, which could be associated with inhibition of protein synthesis, energy depletion, microtubule disaggregation and changes in substrate use, resulting in partial precipitation of both cytoplasmic and nuclear material (Hinton and Laurén 1990). Cellular degeneration and the subsequent necrosis would be the result of oxygen deficiency as a consequence of degeneration or necrosis of gill epithelium and/or vascular dilation observed in hepatic blood vessels, leading to hemosiderosis 
areas (Mohamed 2009). Peliosis areas were found in the fish liver. This pathology may be associated with the direct effect of these trace elements on the sinusoidal endothelial cells, which leads to focal necrosis areas and apoptosis cells (Roy and Bhattacharya 2006). Most of the pathologies found in the liver of Chasicó Lake fishes were reported by other authors (Shah et al. 2009, Višnjić-Jeftić et al. 2010, Jarić et al. 2011), however, peliosis areas were not found. In contrast, Ahmed et al. (2013) reported cellular rupture in hepatocytes of Oreochromis mossambicus that occurs either directly by denaturation of volume-regulating ATPases or indirectly by disruption of the cellular energy transfer processes required for ionic regulation.

The gills are important organs with multiple functions, including gas exchange, osmotic pressure regulation, acid-base balance, ion transport and excretion of nitrogenous waste, which are closely related to chloride cells of epithelial cells in gills (Mallatt 1985). The ATPases $\left(\mathrm{Na}^{+}-\mathrm{K}^{+}\right.$-ATPase, $\mathrm{Ca}^{2+}$-ATPase) in chloride cells serve for ion transport and exchange. The membrane tube system in chloride cells is responsible for energy conversion. The gills are also the primary target of pollutants. Once the gills are damaged, the gas exchange and osmotic pressure regulation functions could be impacted and the fish health could be compromised. Histopathological changes in silversides showed epithelial detachment, necrosis, hyperplasia of mucous cells, edema, telangiectasia and curling of the secondary lamellae. According to Balah et al. (1993), dilation of lamellar blood vessels and edema in secondary lamellae may be due to an increase in the permeability induced by prolonged exposure to these elements. This fluid separates the respiratory epithelium from the underlying tissue with subsequent epithelium detachment and cellular necrosis. The epithelial detachment and necrosis are direct responses to As and $\mathrm{F}^{-}$toxicity, increasing the distance that the toxicant has to travel to reach the blood stream (Mallatt 1985). The observed defense response is hyperplasia of mucous cells, which could inhibit the absorption of $\mathrm{O}_{2}$ and removal of $\mathrm{CO}_{2}$ leading to hypoxia and further exacerbated breathing difficulties (Kumuragura et al. 1982). The hyperplasia of mucous cells and telangiectasia were identified in other reports on contaminants such as chromium (Dhanapakiam et al. 2004), copper (van Heerden et al. 2004) and diesel (Simonato et al. 2008). The report of Dhanapakiam et al. (2004) analyzed the gill damage in Labeo rohita. In contrast to this work, the gills' surface architecture revealed severe changes such as fusion and clumping in the middle and distal parts of the primary lamellae, swelling and cell deterioration.
On the other hand, the interlamellar space was filled with hyperplastic epithelial cells.

In summary, acute and chronic exposure to As and $\mathrm{F}^{-}$may disrupt the osmoregulatory function of fish, cause oxidative stress and alter the gill structure.

\section{CONCLUSION}

The histological changes identified in silversides as analyzed above matched those caused by As and $\mathrm{F}^{-}$in other species, so these pathologies could be associated with exposure to such elements. These findings would support a further mechanistic study on arsenic and fluoride accumulation in liver and gills.

This work represents the first study conducted in the Chasicó Lake about the presence of As and $\mathrm{F}^{-}$in silverside fish tissue and it has shown histopathological changes.

Since silverside is one of the most commercially relevant species in the region and a key species in the food chain (Tinco and Iannacone 2013), further histopathological studies are relevant to guarantee the fish's health and its quality for human consumption.

\section{ACKNOWLEDGMENTS}

Authors express their thanks to Consejo Nacional de Investigaciones Científicas y Técnicas and Universidad de Buenos Aires for financial support.

\section{REFERENCES}

Ahmed M.K. Habibullah-al-Mamun M., Parvin E., Akter M.S. and Khan M.S. (2013). Arsenic induced toxicity and histopathological changes in gill and liver tissue of freshwater fish, tilapia (Oreochromis mossambicus). Exp. Toxicol. Pathol. 65 (6), 903-909.

DOI: $10.1016 /$ j.etp.2013.01.003

APHA (1995). Standard methods for the examination of water and wastewater. 19a ed. American Public Health Association, Washington, $366 \mathrm{pp}$.

Argentine Food Code (1985). Normas generales de los productos alimenticios. Capítulo III, Artículo 156, Resolución 1546. Código Alimentario Argentino. Poder Ejecutivo Nacional, Sistema Nacional de Control de Alimentos.

ATSDR (2002). Toxicological profile for arsenic. Agency for Toxic Substances and Disease Registry, Washington, D.C., 188 pp. 
Avigliano E., Schenone N.F., Volpedo A.V., Goessler W. and Fernández Cirelli A. (2015). Heavy metals and trace elements in muscle of silverside (Odontesthes bonariensis) and water from different environments (Argentina): Aquatic pollution and consumption effect approach. Sci. Total Environ. 506-507, 102-108. DOI: $10.1016 /$ j.scitotenv.2014.10.119.

Balah A.M., El-Bouhy Z.M. and Easa M.E. (1993). Histologic and histopathologic studies on the gills of Tilapia nilotica, Oreochromis niloticus under the effect of some heavy metals. Zagazig Vet. J. 21, 351-364.

Barbier O., Arreola-Mendoza L. and Del Razo L.M. (2010). Molecular mechanisms of fluoride toxicity. Chem. Biol. Interact. 188 (2), 319-333.

DOI: 10.1016/j.cbi.2010.07.011

Bears H., Richards J.G. and Schulte P.M. (2006). Arsenic exposure alters hepatic arsenic species composition and stress mediated-gene expression in the common killifish (Fundulus heteroclitus). Aquat. Toxicol. 77 (3), 257-266.

DOI: $10.1016 /$ j.aquatox.2005.12.008

Bhatnagar C. and Regar B.C. (2005). Neurodegenerative effect of fluoride $(\mathrm{NaF})$ on the brain of fresh water teleost, Labeo rohita. Indian J. Environ. Sci. 9 (1), 15-19.

Bhatnagar C., Bhatnagar M. and Regar B.C. (2007). Fluoride-induced histopathological changes in gill, kidney, and intestine of fresh water teleost, Labeo rohita. Fluoride 40 (1), 55-61.

Bhattacharya A. and Bhattacharya S. (2007). Induction of oxidative stress by arsenic in Clarias batrachus: Involvement of peroxisomes. Ecotoxicol. Environ. Saf. 66 (2), 178-187. DOI: 10.1016/j.ecoenv.2005.11.002

Bonorino A.G., Ruggiero E. and Mariño E. (1989). Caracterización hidrogeológica de la cuenca del arroyo Chasicó. Provincia de Buenos Aires, Comisión de Investigaciones Científicas 44, 1-39.

Camargo J.A. (2003). Fluoride toxicity to aquatic organisms: A review. Chemosphere 50 (3), 251-264.

DOI: $10.1016 / \mathrm{S} 0045-6535(02) 00498-8$

Cao J.L., Chen J.J., Wang J.D., Wu X.T., Li Y.D. and Xie L. (2013). Tissue distributions of fluoride and its toxicity in the gills of a freshwater teleost, Cyprinus carpio. Aquat. Toxicol. 130-131, 68-76.

DOI: $10.1016 /$ j.aquatox.2012.11.022

Chitra T., Reddy M.M. and Ramana Rao J.V. (1983). Levels of muscle and liver tissue enzymes in Channa punctatus (Bloch) exposed to NaF. Fluoride 16 (1), 48-51.

Dhanapakiam P., Sampoorani V., Kavitha M., Ramasamy V.K., Chandrakala A. and Aruna K.C. (2004). Gill lesions in the major carp, Labeo rohita exposed to lethal and sublethal concentrations of tannery effluent. J. Environ. Biol. 25 (3), 333-336.
Datta S., Ghosh D. Saha D.R. Bhattacharaya S. and Mazumder S. (2009). Chronic exposure to low concentration of arsenic is immunotoxic to fish: role of head kidney macrophages as biomarkers of arsenic toxicity to Clarias batrachus. Aquat. Toxicol. 92 (2), 86-94. DOI: 10.1016/j.aquatox.2009.01.002

García-Montalvo E.A., Reyes-Pérez H. and Del Razo L.M. (2009). Fluoride exposure impairs glucose tolerance via decreased insulin expression and oxidative stress. Toxicology 263 (2-3), 75-83.

DOI: $10.1016 /$ j.tox.2009.06.008

Gernhöfer M., Pawert M., Schramm M., Müller E. and Triebskorn R. (2001). Ultra structural biomarkers as tools to characterize the health status of fish in contaminated streams. J. Aquat. Ecosyst. Stress Recovery 8 (3), 241-260. DOI: 10.1023/A:1012958804442

Ghosh J., Das J., Manna P. and Sil P.C. (2008). Cytoprotective effect of arjunolic acid in response to sodium fluoride mediated oxidative stress and cell death via necrotic pathway. Toxicol. in Vitro 22 (8), 1918-1926. DOI: $10.1016 /$ j.tiv.2008.09.010

Haque S., Pal S., Mukherjee A.K. and Ghosha A.R. (2012). Histopathological and ultramicroscopic changes induced by fluoride in soft tissue organs of the airbreathing teleost, Channa punctatus (Bloch). Fluoride 45 (3), 263-273.

Hinton D.E. and Laurén D.J. (1990). Integrative histopathological effects of environmental stressors on fishes. Am. Fish. Soc. Symp. 8, 51-66.

Hughes C.M. (1984). General anatomy of the gills. In: Fish physiology: Gills, vol. 10A (Hoar W.S. and Randall D.J., Eds.), Academic Press, New York, pp. 1-72. DOI: 10.1016/S1546-5098(08)60317-9

Jarić I., Višnjić-Jeftić Z., Cvijanović G., Gačić Z., Jovanović L., Skorić S. and Lenhardt M. (2011). Determination of differential heavy metal and trace element accumulation in liver, gills, intestine and muscle of sterlet (Acipenser ruthenus) from the Danube river in Serbia by ICP-OES. Microchem. J. 98 (1), 77-81. DOI: 10.1016/j.microc.2010.11.008

Kumar A., Tripathi N. and Tripathi M. (2007). Flurorideinduced biochemical changes in fresh water catfish (Calrias batrachus, Linn.). Fluoride 40 (1), 37-41.

Kumuragura A.K., Beamish F.W.H. and Fergnson H.W. (1982). Direct and circulatory path of bermethrin (NRX-14, 3) causing histopathological changes in the gills of rainbow trout. J. Fish Biol. 20, 87-91.

Liu J., Kadiiska M.B., Liu Y., Lu T., Qu W. and Waalkes M.P. (2001). Stress-related gene expression in mice treated with inorganic arsenicals. Toxicol. Sci. 61 (2), 314-320. DOI: $10.1093 /$ toxsci/61.2.314

Kjellevold Malde M., Bjorvatn K. and Julshamn K. (2001). Determination of fluoride in food by use of alkali fusión 
and fluoride ion-selective electrode. Food Chem. 73 (3), 373-379. DOI: 10.1016/S0308-8146(01)00118-2

Mallatt J. (1985). Fish gill structure changes induced by toxicants and others irritants: Statistical reviews. Can. J. Fish. Aquat. Sci. 42 (4), 630-648.

DOI: $10.1139 / \mathrm{f} 85-083$

Mallatt J. and Stinson C. (1990). Toxicant extraction efficiency and branchial $\mathrm{NaCl}$ fluxes in lampreys exposed to Keponc. Arch. Environ. Con. Tox. 19, 307-313.

Metcalfe-Smith J.L., Holtze K.E., Sirota G.R., Reid J.J. and De Solla S.R. (2003). Toxicity of aqueous and sediment-associated fluoride to freshwater organisms. Environ. Toxicol. Chem. 22 (1), 161-166.

DOI: $10.1002 /$ etc. 5620220121

Mohamed F.A.S. (2009). Histopathological studies on Tilapia zillii and Solea vulgaris from Lake Qarun, Egypt. World J. Fish Mar. Sci. 1 (1), 29-39.

Pedlar R.M., Ptashynski M., Evans R. and Klaverkamp J.F. (2002). Toxicological effects of dietary arsenic exposure in lake whitefish (Coregonus clupeaformis). Aquat. Toxicol. 57 (3), 167-189.

DOI: $10.1016 / \mathrm{S} 0166-445 \mathrm{X}(01) 00198-9$

Puntoriero M.L., Volpedo A.V. and Fernández Cirelli A. (2014a). Arsenic, fluoride and vanadium in surface water (Chasicó Lake, Argentina). Front. Environ. Sci. $23(2), 1-5$.

DOI: 10.3389 /fenvs.2014.00023

Puntoriero M.L., Volpedo A.V. and Fernández Cire1li A. (2014b). Biotransferencia de flúor de agua a peces comerciales bonaerenses. Biología Acuática 30, 309-313.

Remes Lenicov M. and Colautti D. (2003). Estudio de la laguna Chasicó (Partido de Villarino y Puán). En: Campaña de relevamientos limnológicos e ictiológicos. Subsecretaría de Actividades Pesqueras, MAA Provincia de Buenos Aires, Informe Técnico Núm. 56, 1-25 [en línea]. http://www.maa.gba.gov.ar/pesca/ relevamientos.php 10/05/2016.

Rosso J.J., Puntoriero M.L., Troncoso J.J., Volpedo A.V. and Fernández Cirelli A. (2011a). Occurrence of fluoride in arsenic-rich surface waters: A case study in the Pampa plain. Argentina. Bull. Environ. Contam. Toxicol. 87 (4), 409-413.

DOI: $10.1007 / \mathrm{s} 00128-011-0358-0$

Rosso J.J., Troncoso J.J. and Fernández Cirelli A. (2011b). Geographic distribution of arsenic and trace metals in lotic ecosystems of the Pampa plain, Argentina. Bull. Environ. Contam. Toxicol. 86 (1), 129-132. DOI: $10.1007 / \mathrm{s} 00128-010-0177-8$

Roy S. and Bhattacharya S. (2006). Arsenic-induced histopathology and synthesis of stress proteins in liver and kidney of Channa punctatus. Ecotox. Environ. Safe. 65 (2), 218-229. DOI: 10.1016/j.ecoenv.2005.07.005
Russell J., Erickson D.R., Mount T.L., Highland J., Russell Hockett E.N., Leonard V.R., Mattson T.D. and Dawson Lott K.G. (2010). Effects of copper, cadmium, lead, and arsenic in a live diet on juvenile fish growth. Can. J. Fish. Aquat. Sci. 67 (11), 1816-1826.

DOI: $10.1139 / \mathrm{F} 10-098$

Schenone N.F., Volpedo A.V. and Fernández Cirelli A. (2007). Trace metal contents in water and sediments in Samborombón bay wetland, Argentina. Wetl. Ecol. Manag. 15 (4), 303-310.

DOI: $10.1007 / \mathrm{s} 11273-006-9030-6$

Schuliga M., Chouchane S. and Snow E. (2002). Upregulation of glutathione-related genes and enzymes activities in cultured human cells by sublethal concentration of inorganic arsenic. Toxicol. Sci. 70 (2), 183-192.

DOI: $10.1093 /$ toxsci/70.2.183

Shah A.Q., Kazi T.G., Arain M.B., Baig J.A., Afridi H.I., Kandhro G.A., Khan S. and Jamali M.K. (2009). Hazardous impact of arsenic on tissues of same fish species collected from two ecosystems. J. Hazard Mater 167 (1-3), 511-515.

DOI: 10.1016/j.jhazmat.2009.01.031

Shi X.T., Zhuang P., Zhang L.Z., Chen L.Q., Liu J.Y., Feng G.P., Wang R.F. and Qu L. (2009). The bioaccumulation of fluoride ion (F) in Siberian sturgeon (Acipencer baerii) under laboratory conditions. Chemosphere 75 (3), 376-380.

DOI: 10.1016/j.chemosphere.2008.12.042

Simonato J.D., Guedes C.L.B. and Martínez C.B.R. (2008). Biochemical, physiological and histological changes in the neotropical fish Prochilodus lineatus exposed to diesel oil. Ecotoxicol. Environ. Saf. 69 (1), 112-120. DOI: 10.1016/j.ecoenv.2007.01.012

Smedley P. and Kinniburgh D. (2002). A review of the source, behavior and distribution of arsenic in natural waters. Appl. Geochem. 17 (5), 517-568. DOI: $10.1016 / \mathrm{S} 0883-2927(02) 00018-5$.

Tinco M.A.C. and Iannacone J. (2013). Bioecology of Phalacrocorax brasilianus (Gmelin, 1789) (Pelecaniformes: Phalacrocoracidae) in South America. The Biologist 11 (1), 151-166.

USEPA (1989). Fluorine (soluble fluoride) (CASRN 7782-41-4). Integrated risk information system, United States Environmental Protection Agency, Washington, DC, [en línea]. http://www.epa.gov/iris/subst/0053 31/10/2016.

USEPA (1993). Arsenic, Inorganic (CASRN 7440-38-2). Integrated risk information system, United States Environmental Protection Agency, Washington, DC, [en línea]. http://www.epa.gov/iris/subst/0278.htm 10/10/2016.

Van Heerden D.V., Voslo A. and Nikinmaa M. (2004). Effects of short-term copper exposure on gill structure, metallothionein and hypoxia-inducible factor-1 
(HIF-1) levels in rainbow trout (Oncorhynchus mykiss). Aquat. Toxicol. 69 (3), 271-280.

DOI: $10.1016 /$ j.aquatox.2004.06.002

Višnjić-Jeftić Z., Jarić I., Jovanović L, Skorić S., Smederevac-Lalic M., Nikcević M. and Lenhardt M. (2010). Heavy metal and trace element accumulation in muscle, liver and gills of the Pontic shad (Alosa immaculate) (Bennet 1835) from the Danube river (Serbia). Microchem. J. 95 (2), 341-344.

DOI: $10.1016 /$ j.microc.2010.02.004

Wang A.G., Xia T., Chu Q.L., Zhang M., Liu F., Chen X.M. and Yang K.D. (2004). Effects of fluoride on lipid peroxidation, DNA damage and apoptosis in human embryo hepatocytes. Biomed. Environ. Sci. 17 (2), 217-222.
Wrobel K., Parker B., Kannamkumarath S.S. and Caruso J.A. (2002). Determination of As (III), As (IV), monomethylarsonic acid, dimethylarsinic acid and arsenobetaine by HPLC-ICP-MS: Analysis of reference material, fish tissue and urine. Talanta 58 (5), 899-907. DOI: 10.1016/S0039-9140(02)00404-6

Zárate M.A., Schultz P.H., Blasi A., Heil C., King J. and Hames W. (2007). Geology and geochronology of type Chasicoan (late Miocene) mammal-bearing deposits of Buenos Aires (Argentina). J. South Amer. Earth Sci. 23 (1), 81-90.

DOI: $10.1016 /$ j.jsames.2006.09.018 